\title{
CREATIVITY AND SPONTANEITY IN THE THEORY OF THE COMMUNITY POWER LEARNING PROCESS
}

\author{
Tuovi Leppänen ${ }^{1, *}$ (10
}

\begin{abstract}
In this article, the study of community power learning process is introduced. The aim of the study was to build a conception and a substantive theory of adult learners' group learning. The theory has a dialogue with three perspectives: andragogy, sociometry and neuroscience. The community power learning process builds a close connection with Morenian approaches of using sociometry, peer support and spontaneity and creativity in a group learning process. Spontaneity and creativity are seen as an essential part of adult group learning. Four main categories were found: participation, communality, creativity, and tutoring. The core category was identified as the community power learning process. This study has been carried out using grounded theory research methodology.
\end{abstract}

KEYWORDS: Pedagogy; Spontaneity; Creativity; Adults.

\section{CRIATIVIDADE E ESPONTANEIDADE NA TEORIA DO PROCESSO DE APRENDIZADO DE PODER DA COMUNIDADE}

\section{RESUMO}

Neste artigo, é apresentado o estudo do processo de aprendizado de poder da comunidade. O objetivo do estudo era construir uma concepção e uma teoria substantiva da aprendizagem em grupo de alunos adultos. A teoria dialoga com três perspectivas: andragogia, sociometria e neurociência. O processo de aprendizagem de poder da comunidade constrói uma conexão próxima com abordagens morenianas de uso de sociometria, apoio de pares, espontaneidade e criatividade em um processo de aprendizagem em grupo. A espontaneidade e a criatividade são vistas como uma parte essencial da aprendizagem de um grupo de adultos. Quatro categorias principais foram encontradas: participação, comunalidade, criatividade e tutoria. A categoria central foi identificada como o processo de aprendizagem de poder da comunidade. Este estudo foi realizado utilizando a metodologia de pesquisa da teoria fundamentada.

PALAVRAS-CHAVE: Pedagogia; Espontaneidade; Criatividade; Adultos.

\section{CREATIVIDAD Y ESPONTANEIDAD EN LA TEORÍA DEL PROCESO DE APRENDIZAJE DE PODER COMUNITARIO}

\section{RESUMEN}

En este artículo se introduce el estudio del proceso de aprendizaje del poder comunitario. El objetivo del estudio era construir una concepción y una teoría sustantiva del aprendizaje grupal de estudiantes adultos. La teoría dialoga con tres perspectivas: andragogía, sociometría y neurociencia. El proceso de aprendizaje del poder de la comunidad crea una conexión cercana con los enfoques morenianos del uso de la sociometría, el apoyo de pares, la espontaneidad y la creatividad en un proceso de aprendizaje grupal. La espontaneidad y la creatividad se consideran una parte esencial del aprendizaje grupal de adultos. Se encontraron cuatro categorías principales: participación, comunalidad, creatividad y tutoría. La categoría principal se identificó como el proceso de aprendizaje de poder comunitario. Este estudio se ha llevado a cabo utilizando la metodología de investigación de teoría fundamentada.

PALABRAS CLAVE: Pedagogía; Espontaneidad; Creatividad; Adultos.

1.CoPoS - Community Power Services - Laukaa, Finland.

*Corresponding author: tuovi.leppanen@copos.fi

Section editor: Graziela M S Gatto

Received: 20 May 2021 | Accepted: 21 Jul. 2021 


\section{INTRODUCTION}

This summarising article is based on the writer's dissertation of the subject (Leppänen, 2018). The motivation for this research emerged from pondering about what happens in a group when a teacher focuses on students instead of teacher's own action during learning sessions. In recent studies and literature, learning is seen as learners' active participation, while teaching is seen as a facilitation of learning (Forsyth, 2016). In related literature, the focus is often on the teacher's actions and the interpretation of the group instead of the students' own voice and experience (Rachal, 2002). In educational research, the group has been recognised as an essential part of the learning process, but a deep analysis of the meaning of the group is still needed (Merriam \& Bierema, 2013).

The framework for this study is andragogy, which places adult learners' life context at the centre of the learning process. Andragogy includes adult education organisations and the science of adult learning. It has been an academic discipline since the beginning of the 20th century. Using John Dewey's pragmatic paradigm of education as a basis, several researchers have developed andragogical theory and practices (Jarvis, 2010). The first developer of adult group learning was Eduard C. Lindeman (Brookfield, 1987).

The social dimension of learning and adult learners' social roles, such as the role of a mother or worker, are internal themes in adult learning theories. Social roles have been considered a supporting aspect in the adult learning process. For instance, Lee (2003) has criticised the western tendency to see international students as a uniform group, with their cultural differences and features not being taken into account in group learning processes. However, analyses of intersubjectivity, interaction, peer aspects and adult learners' own experience in adult group learning processes are still missing from andragogical research. Since Lindeman's time, theorists have not focused on the group as a learning cell in adult learning processes. Therefore, further empirical research and development of andragogical theory in a group learning context is needed (Taylor \& Kroth, 2009, p. 2).

\section{GROUNDED THEORY RESEARCH METHODOLOGY}

Grounded theory research methodology covers the whole research process from data collection to analysis. The core idea is to generate theory in a systematic and analytic process where the experience of the human being is understood as closely as possible. The phenomenon of the data will be processed, and based on the process the theory will be generated. The theory will be formed gradually in an open interaction between a researcher and data. It requires flexibility and theoretical sensitivity on the researcher's part (Glaser, 1992; Glaser \& Strauss, 2008).

Hypotheses are suggestive in the beginning of the grounded theory process, and they will be sharpened during a research process. In a theory generation process, hypotheses will be developed and a researcher will start to verify them through constant comparison. Therefore, a theory is not a complete product; instead, it is a theory as a process, an ever-developing entity. Hence, grounded theory is a relevant methodology in order to analyse different social realities. It is possible for a format of generated theory to be substantive or formal. In this research, the theory is substantive, based on data and students' subjective experience is under focus.

Substantive theory is always context-based, whereas formal theory is not context-based but instead gives an explanation to some conceptual structure or phenomenon, e.g. power or integration. Based on several substantive theories or research contexts from the same research interest, it is possible to build a formal theory (Glaser, 1978, p. 2, 1992, pp. 15-16; Glaser \& Strauss, 2008).

The researcher's research profile consists of the researcher's perception of the world, philosophy of science, research interest and a theoretical view of the research. In this study, the researcher's profile builds on long-term experience as a group leader in various groups and being a trainer in numerous pedagogical groups. In addition, a long-term training of sociodrama and psychodrama has built a presupposition and theoretical sensitivity of the researcher, without forgetting the researcher's own participation in several groups as a group member. 


\section{RESEARCH DESIGN}

The informants for this study were a group of 12 adult teacher students from six different countries. All group members lived in Finland during the research period. Three of the students were female, and nine were male. All of them had at least one higher education degree. The working language was English, but none of the participants spoke it as a mother tongue. Socioeconomic context is not significant in grounded theory analysis, provided it does not become significant during the process (Glaser, 1978, p. 60,1992, p. 5). In this study, the focus is on the phenomenon of group learning, rather than international groups as such.

The research data was collected during teacher studies. The teacher studies were implemented once a month on a seminar basis, and the students met eight times. The group was informed of this before the studies. The research data consists of individual learning diaries, group learning diaries, two recorded group discussions and students' portfolios of their studies. The aim of the learning diaries, discussions and portfolios was to reflect the students' study and learning experiences. The international feature of the group became significant in the data collection. Many countries and learning cultures do not support a reflective writing style, therefore, a reflective writing style was not expected. In the analysis phase, all sentences and comments concerning other learners, the study group and the trainer were collected.

In this study, the researcher had a participatory role in the research context. Glaser (2008, p. 48) suggests full participation in data collection in order to ensure the researcher's possession of the data. The risk is that without full participation, a researcher is not competent to build a theory of data.

Research questions are set so that it becomes possible to specify a phenomenon but not to define it (Glaser, 1992; Glaser \& Strauss, 2008). This study was guided by two research questions:

1. How do adult learners describe their group learning experiences?

2. What kind of substantive theory can be built based on their experiences?

\section{ANALYSING PROCESS}

In this phase, research data was examined by using a glaserian inductive data analysis. It includes four parts: open coding, theoretical coding, verification and theory writing. In the open coding process, the phenomenon of the data was nominated. Each sentence was given a code, which describes the core content of the sentence. The purpose was to find as many codes as possible. Codes are properties or dimensions of a phenomenon. Properties and dimensions are near data and they are concrete descriptions of a phenomenon (Glaser, 1978).

During a coding process, a researcher gets lots of ideas of phenomenon and theory. Glaser (1978) suggests to stop the coding process and instead write a memo of the idea that has emerged. Memos are key findings for the later theorising phase, because they help find connections between codes. All codes were phrased as a gerund, because they are explaining what is happening in the phenomenon. Gerund is describing the process, what a phenomenon is like. In this process gerund describes what kind of process the group learning is. The researcher did a role reverse with sentences in order to understand samples. She read one sample several times in order to understand the writers' experience and world. Glaser and Strauss (2008, p. 225) say that a researcher feels data "in his bones". Role reverse is a method to feel data in the researcher's bones.

Theoretical coding is the second step in the grounded theory process. In theoretical coding, all open codes are spread out in front of a researcher, and the researcher starts to find out relationships between the codes. This is a grouping process of codes. The code groups are keys for categories, which are more abstract concepts than codes. Categories describe theoretical ideas of the code groups. A theoretical meaning of concepts and hierarchy between categories starts to emerge. In that phase, a researcher needs to ensure that there are no new properties or categories 
in the data. That is called the saturation of categories. Theoretical coding offers, to a researcher, a way out from an empirical level to the conceptual level of the phenomenon. Theoretical coding is a process where the order of properties and categories varies, and gradually a researcher learns the power of grounded theory analysis (Glaser, 1978). In this research, open codes were grouped according to similar kinds of properties. The similar properties got one concept to describe them. In the process, properties and concepts still varied, and gradually they found their order.

The third phase of the grounded theory analysis is the verification of the conceptual order. In the verification phase, a researcher once again compares properties and concepts with each other, looking for similarities and differences between them. This process constructs the final structure of the emerging theory. The number of properties and concepts decreases, and the researcher builds a figure where the properties are set under subcategories and the subcategories are set under the main categories. This is the conceptual model, which crystalises the data into theory. The theory explains the whole data, and no new content arises (Glaser \& Strauss, 2008, pp. 109-113). In this research, the final number of properties and dimensions is 19 , and these were grouped under nine subcategories, which in turn amounted to four main categories.

The final phase of generating theory is theory writing, grounding the theory. The previous conceptualisation process allows the core category to emerge. All main categories are integrated into the core category. The core category covers all other categories and explains the phenomenon. In the reporting phase, a researcher describes how the theory was built based on data. Theory writing takes place at a conceptual and phenomenal level. In the final phase of theory writing is a theoretical discussion where the generated theory is settled to the connection with other theories (Glaser, 1978; Glaser \& Strauss, 2008).

\section{KEY FINDINGS OF ANALYSES}

In this study, four main categories were identified in the analysis of the data:participation, communality, creativity and tutoring. The significant questions in the first main category, participation, are: who am I in this group, who are the other group members, and how is this group structured. In the first category, 'belonging to the group', other group members were experienced as a positive resource for one's own teacher studies. In the other category, 'not belonging to the group', there was the experience of rejection. "The second category, communality, was formed by three properties: being joined, commitment, and building a learning process. In this category, the individual perspective starts to become a communal perspective, and the focus shifts to group-level learning” (Leppänen, 2018, p. 137).

The idea of communality strengthened from the 'being joined' category towards the 'building a learning process' category. 'Being joined' was a voluntary action, and students carried the sense of the group in their minds even when they were unable to participate in the seminar. In the 'commitment' category, there was an experience of attraction to the group as well as a commitment to working for the group in order to ensure a good result for everyone in the group. There was a strong internal motivation. In the category of 'building a learning process', the properties of empathy, group atmosphere and learning partnership were found. Empathy strengthened the group atmosphere, and it was a way the learning partnership.

"The third category, creativity, includes comparison and new emergence, and there can be reflection, new insights and new learning” (Leppänen, 2018, p. 137). Other categories, such as participation and communality, merge with that of creativity. Questions about participation and communality are part of creativity. Finally, the group sees what it has learnt during the group-learning process. In the beginning of the learning process, no one knew the results of the process. The results were unpredictable for the group members. When the learners got the opportunity to challenge their ideas, it strengthened their opinions, views and dreams concerning the future. "The first three categories express the relationships between group members. The fourth category, tutoring, diverges from previous categories in that it is a description of the relationship between a tutor and the group members" (Leppänen, 2018, p. 137).

There were properties which were not explained by other categories, although there are features from them. Therefore, the tutoring category works as a linkage category. "The tutoring category consists of two future 
sub-categories, structuring and securing” (Leppänen, 2018, p. 137). Structuring means that a tutor creates physical and mental frames for the group. In addition, a tutor promotes a learning process with their pedagogical competences. The securing category has two dimensions where a tutor offers support to the group as well as control over studies and learners. "The tutoring category enables participation, strengthens the feeling of communality, and establishes the preconditions to creativity" (Leppänen, 2018, p. 137).

Glaser (1978, p. 18) says that the core category is in the researcher's mind before they become aware of it. In this research, the group started to build a core category. It was in the form of group cohesion and attraction. The core category was then named the community power learning process.

\section{THEORY OF THE COMMUNITY POWER LEARNING PROCESS}

The data analyses indicated that the group contains four sub-processes: participation, communality, creativity and tutoring. These four sub-processes are, in turn, preconditions of the community power learning process. Participation is a precondition of communality, just as communality is a precondition of creativity. These three preconditions call for the fourth precondition, tutoring. These are the qualitative properties of the community power learning process: persistence, encountering and freedom. Persistence ensures that, despite the challenges, the community power learning process coheres (Leppänen, 2018, p. 137).

Cooperation and encounters produce persistence in the group. The group is felt as being attractive, and learners are ready to commit to it. It is also found that learners' needs and expectations are encountered in the process. The community power learning process met the expressed needs and expectations of learners. Needs of being seen and getting support and empathy are included in encountering, but equal cooperation and responsibilities were also expected in the group. This often took place in a concrete manner in face-to-face situations between students and the tutoring teacher.

"The community learning process is a free process which allows learners to be the kind of person that they already are" (Leppänen, 2018, p. 137). E.g., creativity required a free atmosphere, even if it occurred in a social and tutored structure, so active tutoring is required. Freedom also allowed weighting up and criticisms. "Forcing freedom into the community power learning process, however, is impossible, as the group is free to create what it creates" (Leppänen, 2018, p. 137).

"In the theory of community power learning process, all sub-processes form a close continuum and they can occur simultaneously. Therefore, the community power learning process, as a basic social process, is porously chained and entangled" (Leppänen, 2018, p. 137). As Glaser (1978, pp. 101-102) says, the basic social process describes the changing process of the phenomenon. The chained and entangled basic social process describes individual and communal changes inside the community power learning process.

The experiences in the community power learning process occur simultaneously on an individual level - based on each participant's personal and cultural interpretation - as well as on the level of the entire group. Therefore, the community power learning process builds a new social reality within a learning community. This enables the development of a new social reality, which in this research community is multicultural. In this way, the community power learning process, as a basic social process, can also promote cultural change (Leppänen, 2018, pp. 137-138). 


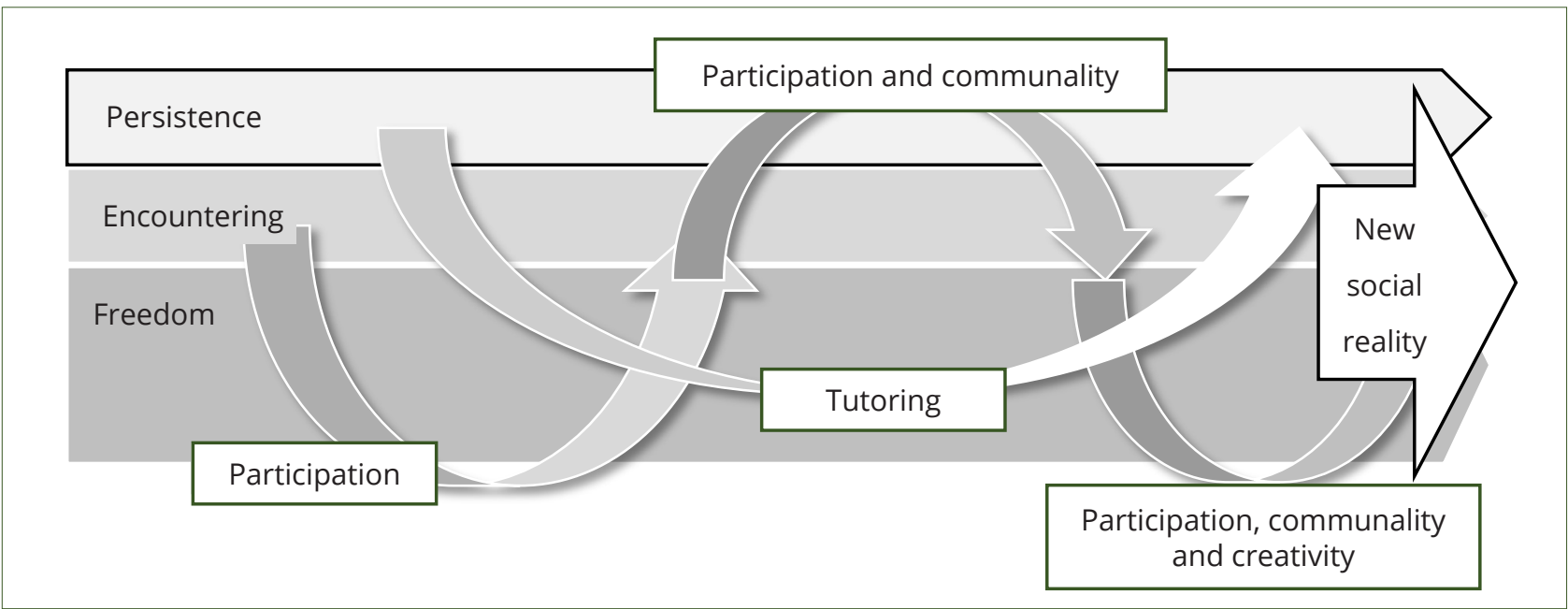

Figure 1. The theory of the community power learning process

\section{THEORETICAL DISCUSSION}

The main idea of theoretical discussion is to find connections between the new theory and existing literature, although the purpose is not to find the same meaning of the conceptions. Rather, the purpose of integration is finding partnership between the new theory and other theorists (Glaser, 1978).

In this study, the theory of the community power learning process had a dialogue with three perspectives: andragogy, sociometry and neurosciences. Eduard C. Lindeman (1885-1953) was a pioneer of adult learning who focused on the group in adult learning. In addition, a strong commitment to democracy belonged to Lindeman's ideology. The purpose of adult education is to give meaning to one's whole life. Lindeman saw that welfare and meaningful action of small groups are the basis for a strong democratic society, where teachers are agents of democracy (Lindeman, 1926, 1932).

Jacob Levy Moreno's (1889-1974) aim was to open nodes in human relationships and social interaction. He conducted extensive studies in order to understand the relationships between people. He named these studies sociometry. Three of his core concepts are used in this discussion. They are encounter, spontaneity and creativity (Moreno, 1946, p. 1978). Moreno suggests spontaneity as a way to integrate all subjects in education in order to develop students' personality and learning processes (Moreno, 1946, p. 1978). The Morenian approach is considered to be one of the experimental learning approaches in education (Propper, 2003, p. 229).

Damasio (b. 1944) represents $(2000,2011)$ the branch of neuroscience research, which focuses on connections between human minds. He says that emotions use a human body as a stage of their expressions, and that life is a drama caused by consciousness. Emotions are shared between cultures, but their expressions are culturally contextual.

During the last few decades, the research collaboration between education sciences and neurosciences has become more significant in order to develop learning and learning contexts (Jarvis, 2010; Immordino-Yang \& Damasio, 2007). In the light of neuroscience research, learning, emotions, body and cultural context are more deeply intertwined than previously known. Studies have been conducted that show that emotions are the basis of essential cognitions in learning (Immordino-Yang \&Damasio, 2007.)

Immordino-Yang (2008) says that mirror neurons are the basis of social dimension in learning. The social dimension contains cognitions and behaviour, as well as sociocultural reality with experiences, emotions and cultural features. All of them are transmitted between learners in sociocultural situations through the mirror neuron system. There is a connection between two creative minds. However, perfect understanding is impossible and we always speak about interpretation, even if it enables understanding between representatives of two different cultures.

\section{DISCUSSION OF THE COMMUNITY POWER LEARNING PROCESS}

Participation was seen as the core sell of the group learning in all theories. Lindeman (1921) emphasised the comprehensive experience of belonging to a group. He says that the experience broadens the consciousness of one's own 
role in a community. People who know their role in a community can strengthen that community. Participation in the community power learning process and the experience of belonging to a group are the basis of the group learning process. In addition, neuroscience research supports the meaning of participation in learning processes. Studies have shown that face-to-face communication builds a common reality, which allows communal and creative processes (Iacoboni, 2008). In the Morenian approach (Moreno, 1934, 1978), sociometric methods provide tools for strengthening participation in groups. Participation includes the concepts of the encounter, spontaneity and creativity.

In the participation process, there was a dimension of not belonging to the group. According to Moreno (1978), sociatric methods could be used for conflict solving supporting participation in the community power learning process.

The next sub-process of the community power learning process, communality, was seen as the essential concept in all theories. In the community power conception, it was formed in a process of joining, commitment and building a learning process. In neuroscience, the property of empathy was considered the cornerstone of social interaction and communality. Mirror neurons allow the forming of empathy, especially in the face-to-face interaction conveying solidarity, commitment and a feeling of togetherness (Gallese, 2004, 2011; Iacoboni, 2008).

In the Morenian approach, the concept of the positive tele supports the development of communality. A positive tele is silence and mutual understanding between two or more people. Moreno defined tele as a situational insight, a feeling and an appreciation for another person (Moreno, 1978, pp. 311-312.).

A shared learning process was the essential property in the communality. Lindeman (1926) says that an adult learner wants to share the whole of their personality and reality with other learners. Sharing personal experiences develops expertise and meaningful social action in small groups.

In the community power learning process, creativity was seen as an unexpected outcome of the learning process. No teacher or students could know the final result of the learning process before it emerged. Creativity required intellectual challenges and a free atmosphere. In the Morenian approach, creativity is an unexpected result of spontaneous interaction between people. When students are learning in a spontaneous interaction, it is possible to apply learning outcomes in other real situations (Moreno, 1946).

In andragogy, creativity has been seen as an intellectual challenge that improves the learner's expertise. Lindeman (1926) says that one's whole life is a source of learning, and that life and creativity regenerate adulthood. Group action and structured learning discussions are required in order to reach a creative and regenerating learning process.

Creativity is a key feature that is needed in order to survive in social situations in different cultural contexts, according to neuroscience research. Human creativity requires understanding of social feedback. It produces innovations in sciences, art and technology, as well as social innovations like moral and ethics (Immordino-Yang \& Damasio, 2007). According to neuroscience hypotheses, creativity allows the editing of the autobiographical self (Damasio, 2000).

Tutoring, as a final sub-process of the community power learning process, was considered a cohesive process. It was seen as a method that structures and secures the learning process. The tutoring process follows the whole learning process. In andragogy, Lindeman $(1926,1935)$ considers the tutoring process to be a creative action, which allows adult learners to express their full abilities and expertise. A tutor helps a group find out their own ideas and insights freely, without ready answers. In this process, a tutor should use the whole of their life experience and expertise. This is called democratic leadership in a learning context. The democratic leadership in the learning context builds the structure of the democratic society.

In neuroscience, research has shown that the more a teacher imitates the students, the more the students trust the teacher; consequently, students are more satisfied with their own learning results, and the results are generally better (Zhou, 2012, p. 66).

In the Morenian approach, the group building is based on encountering and acting. Encountering means a deep process where an individual has a free space to be with their own strengths and weaknesses. Two or more people encounter each other within their own rights. It is always the situational process, where "you" and "me" as a person is present and the group process is able to develop. In the learning situation, encountering means that a learner is encountered as a holistic person. It can remove barriers of learning (Moreno, 1946, 1978). 
The Morenian concept of spontaneity is near the concept of freedom in the community power learning process theory. According to Moreno (1946, 1978), learning spontaneity is necessary because the emphasis of the content divides the learner's personality into the content-person and the action-person. The learning of spontaneity is a holistic process that goes from the mind to the body and vice versa. Therefore, spontaneity supports holistic learning. When abstract content is brought to the active and creative level, it enhances the autonomy of learners and learning groups.

\section{CONCLUSIONS}

The aim of this research was to obtain a holistic understanding of the group as a phenomenon based on learners' experience of such learning. Grounded theory was used as the research methodology. Grounded theory enabled the generation of a data-based theory that could be applied in the theoretical development of andragogy. Such development is necessary in order to guarantee high-quality adult education in the future based on the adult learners' life situation, scientific knowledge and democratic values (Leppänen, 2018, p. 139).

The substantive theory of the community power learning process was generated through a systematic and analytical research process. The concepts of main categories are familiar in social and educational science conception, but in this substantive theory, concepts received their content from the data.

The theory of the community power learning process offers new perspectives on group-based learning theories in andragogy. It structures the adult group learning process and the group as a phenomenon in a new way. The generated substantive theory explains a learning group as a phenomenon through the group members' own experiences. The generated theory helps to understand the properties of the group process and see the comprehensiveness of the phenomenon (Leppänen, 2018, p. 139).

The Morenian concepts, spontaneity and creativity and other theories support the conceptions of the generated theory. Based on the community power learning process, it is possible to build up the new multicultural social reality in various learning contexts. The substantive theory can be applied in different contexts and modified for different group contexts. It will also be very useful to develop learning by combining Moreno's psychodrama methodology and the theory of the community power learning process. Giacomucci (2021) has developed Morenian group-based methdology in social work education and May and Maravel (2020) have studied identifying needs of teaching-learning processess and effectiveness of psychodramatic techniques in the university setting. The use of spontaneity and creativity to support group learning processes could be developed in the future in cooperation at the global level.

Educational organisations need to understand the uniqueness of learners and the meaning of the shared learning processes in groups. Learning is the result of the dynamic motor and cognitive interaction, which needs to be tutored in an empathic and supportive social atmosphere. The substantive theory of the community power learning process can be seen to represent a learner-centre paradigm, where each learner's potential is allowed to emerge and work as a centre of learning. The theory also confirms the assumption that an adult learner genuinely wants to commit to a group and encounter their own needs and expectations. Human-based pedagogy, which emphasises communality and creativity, is valued in adult education, and it should not be subordinated to the aims of technology. "Ultimately, andragogic adult education is the growth process supported by other learners and a tutoring teacher. As the substantive theory developed in this study suggests, the community power learning process serves the aims of the adult learners' growing process" (Leppänen, 2018, p. 140).

\section{DATA AVAILABILITY STATEMENT}

Data will be sent upon request. 


\section{FUNDING}

Not applicable.

\section{ACKNOWLEDGMENT}

I would like to thank my international students, who gave me such a rich data to develop the theory of the community power learning process. I would also like to thank all my supervisors and trainers for the high quality psychodrama and sociodrama education that has given me a strong competence to develop the Morenian methodology in teaching.

\section{REFERENCES}

Brookfield, S. (1987). Learning democracy: Eduard Lindeman on adult education and social change. Croom Helm.

Damasio, A. (2000). Tapabtumisen tunne: Miten tietoisuus syntyy. Hakapaino.

Forsyth, D. R. (2016). College teaching: Practical insights from the science of teaching and learning. Professor's guide to teaching. (2 ${ }^{\text {nd }}$ ed). American Psychological Association. https://doi.org/10.1037/14777-000

Gallese, V. (2004). The manifold nature of interpersonal relations: The quest for a common mechanism. In C. D. Frith \& D. M. Wolpert (Eds.), The neuroscience of social interaction: Decoding, imitating, and influencing the actions of others (pp. 160-182). Oxford University Press.

Giacomucci, S. (2021). Social Work, sociometry, and psychodrama: Experiential Approaches for group therapists, community leaders, and social workers. Springer. https://doi.org/10.1007/978-981-33-6342-7

Glaser, B. G. (1978). Theoretical sensitivity: Advances in the methodology of grounded theory. Sociology Press.

Glaser, B. G. (1992). Basics of grounded theory analysis. Sociology Press.

Glaser, B. G., \& Strauss, A. L. (2008). The discovery of grounded theory: Strategies for qualitative research. (3 ${ }^{\text {rd }}$ ed). Aldline Transaction.

Iacoboni, M. (2008). Ibmisten peilaus: Kytkeytymisemme uusi tiede. Hakapaino.

Immordino-Yang, M. H., \& Damasio, A. (2007). We feel, therefore we learn: The relevance of affective and social neuroscience to education. Mind, brain, and education, 1(1), 3-10. https://doi.org/10.1111/j.1751228X.2007.00004.x

Immordino-Yang, M. H. (2008). The smoke around mirror neurons: Goals as sociocultural and emotional organizers of perception and action in learning. Mind, brain and education, 2(2), 67-73. https://doi.org/10.1111/ j.1751-228X.2008.00034.x

Jarvis, P. (2010). Adult education and lifelong learning: Theory and practice. Routledge.

Leppänen, T. (2018). Yhteisövoimainen oppimisprosessi: Substantiivinen teoria aikuisten ryhmässä oppimisen kokemuksista. [PhD thesis] Jyväskylän yliopisto, Jyväskylä.

Lindeman, E. C. (1921). The Community: An introduction to the study of community leadership and organization. Association Press.

Lindeman, E. C. (1926). The Meaning of Adult Education. New Republic, Inc.

Lindeman, E. C. (1932). Goals and methods of adult education. In S. Brookfield (1987), Learning Democracy: Eduard Lindeman on adult education and social change (pp. 39-42). Croom Helm.

Lindeman, E. C. (1935). The place of discussion in the learning process. In S. Brookfield (1987). Learning Democracy: Eduard Lindeman on adult education and social change (pp. 43-47). Croom Helm. 
Maya, J., \& Maravel, J. (2020). Teaching-Learning Processes: Application of Educational Psychodrama in the University Setting. International Journal of Environmental Research and Public Health, 17(11), 3922. https:// doi.org/10.3390/ijerph17113922

Merriam, S. B., \& Bierema, L. L. (2013). Adult learning: Linking theory and practice. Jossey-Bass.

Moreno, J. L. (1934). The sociometric test. In J. Fox (Ed.) (1987), The essential Moreno: Writings on psychodrama, group method and spontaneity by J. L. Moreno (pp. 102-112). Springer.

Moreno, J. L. (1946). Psychodrama (Vol. 1). Beacon.

Moreno, J. L. (1978). Who shall survive? Foundations of sociometry, group psychotherapy and sociodrama ( ${ }^{\text {rd }}$ ed.). Beacon.

Propper, H. (2003). Psychodrama as experiential education: Exploring literature and enhancing a cooperative learning environment. In J. Gershoni (Ed.), Psychodrama in the 21 st century (pp. 229-248). Springer Publishing Company.

Rachal, J. R. (2002). Andragogy's detectives: A critique of the present and a proposal for the future. Adult Education Quarterly, 52(3), 210-227. https://doi.org/10.1177/0741713602052003004

Taylor, B., \& Kroth, M. (2009). Andragogy's transition into the future: Meta-analysisi of andragogy and its search for a measurable instument. Journal of Adult Education, 38(1), 1-11.

Zhou, J. (2012). The effects of reciprocal imitation on teacher-student relationships and student learning outcomes. Mind, Brain and Education, 6(2), 66-67. https://doi.org/10.1111/j.1751-228X.2012.01140.x 